\title{
A 6-Hour Nocturnal Interruption of a Continuous Subcutaneous Insulin Infusion: 1. Metabolic and Hormonal Consequences and Scheme for a Prompt Return to Adequate Control
}

\author{
G. Krzentowski, A.Scheen, M.Castillo, A. S. Luyckx and P.J.Lefèbvre \\ Division of Diabetes and Division of Clinical Pharmacology, Institute of Medicine, University of Liège, Liège, Belgium
}

\begin{abstract}
Summary. Interruption of a continuous subcutaneous insulin infusion, most often due to technical problems occurring during the night, is a not uncommon event whose metabolic consequences have received relatively little attention until now. We have therefore investigated the changes in blood glucose, plasma non-esterified fatty acids, 3-hydroxybutyrate, glucagon and free insulin in eight $\mathrm{C}$-peptide negative Type 1 diabetic patients whose pumps were deliberately stopped between $23.00 \mathrm{~h}$ and $05.00 \mathrm{~h}$. A control test with the pump functioning normally was carried out in each patient and the studies were randomized. Considering the values at $23.00 \mathrm{~h}$ as reference, interruption of the insulin infusion resulted in (1) a rapid decrease in plasma free insulin significant after $1 \mathrm{~h}$ and reaching a nadir of $6 \pm 2 \mathrm{mU} / 1$ after $6 \mathrm{~h}$; (2) a rise in blood glucose which was significant at hour 3 and reached $17.4 \pm$ $1.9 \mathrm{mmol} / 1$ at hour 6 ; (3) a moderate increase in plasma nonesterified fatty acids which remained in the range of $700-800 \mu \mathrm{mol} / 1$; (4) an early and linear rise in plasma 3-
\end{abstract}

hydroxybutyrate, significant after $1 \mathrm{~h}$ and averaging $1290 \pm$ $140 \mu \mathrm{mol} / 1$ after $6 \mathrm{~h} ;(5)$ a late increase (hour 5) in plasma glucagon. The second aim of our study was to provide for the patient a precise scheme of insulin supplements administered via the pump and based on blood glucose monitoring (Dextrostix - Glucometer) and semi-quantitative evaluation of ketonuria (Acetest). Resetting the pump at its basal rate at $05.00 \mathrm{~h}$ and giving insulin supplements $(2-8 \mathrm{U})$ at $06.45 \mathrm{~h}$ (with the usual breakfast dose) and again at $10.00 \mathrm{~h}$ have proved efficacious in restoring satisfactory metabolic control by noon the day after starting the experiment. These results form practical recommendations to patients undergoing this type of accident.

Key words: Continuous subcutaneous infusion, Type 1 diabetes, glucagon, insulin, management, non-esterified fatty acids, pump.
The major importance of good metabolic control in all forms of diabetes is now well documented [1]. In Type 1 (insulin-dependent) diabetic patients, continuous subcutaneous insulin infusion (CSII), using small portable pumps, has been proposed to attain this goal, with encouraging results [2-5]. A hazard of this treatment is the fortuitous interruption of the subcutaneous insulin delivery due to failure of the pump or delivery system. Until the recent publication of Pickup et al. [6], this question had received relatively little attention [7]. The aim of the present study was (1) to perform a detailed analysis of the hormonal and metabolic changes occurring during a $6 \mathrm{~h}$ nocturnal interruption of CSII in Type 1 diabetic patients; (2) to provide a precise scheme for a prompt return to adequate control. For this second part of the study, the scheme was designed to be usable by the patient himself on the basis of blood glucose monitoring and semi-quantitative evaluation of ketonuria.

\section{Material and Methods}

\section{Subjects}

The study was approved by the Ethical Committee for Human Investigations of our Institution and all subjects gave their free and informed consent. Eight Type $1 \mathrm{C}$-peptide negative diabetic patients participated in the study. Individual data are given in Table 1.

\section{Experimental Procedures}

The patients, who had been accustomed to their 1001 HM Mill Hill Infuser for 5-10 days, used it at $17.45 \mathrm{~h}$ to deliver their usual pre-dinner insulin dose $(8.4 \pm 1.1 \mathrm{U})$; dinner was taken from 18.00 to $18.30 \mathrm{~h}$. At $22.00 \mathrm{~h}$, a catheter was inserted in an antecubital vein. At $23.00 \mathrm{~h}$, the pump was stopped by removing the battery. At $05.00 \mathrm{~h}$, the pump was reactivated at its basal rate $(1.1 \pm 0.2 \mathrm{U} / \mathrm{h})$. At $06.45 \mathrm{~h}$, the subjects made their usual pre-breakfast 'clicks' (handling the knob of the MillHill Infuser to deliver boluses of insulin makes a 'click' which corresponds to the delivery of a certain amount of insulin depending upon the insulin concentration in the syringe; in the present investigation, 
Table 1. Clinical characteristics of eight Type 1 diabetic patients

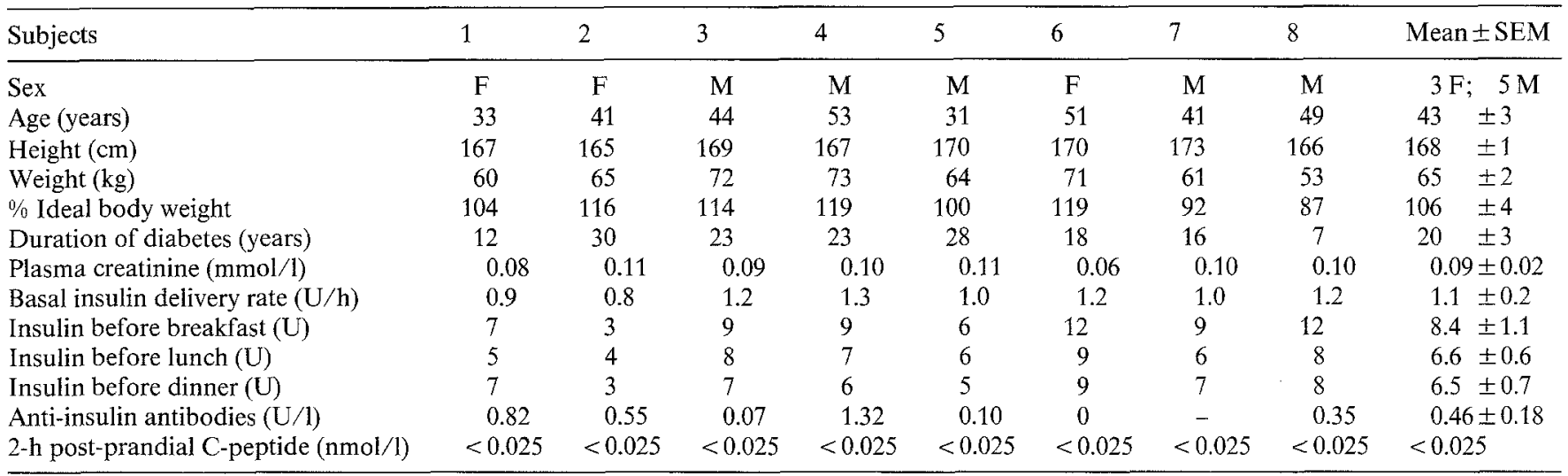
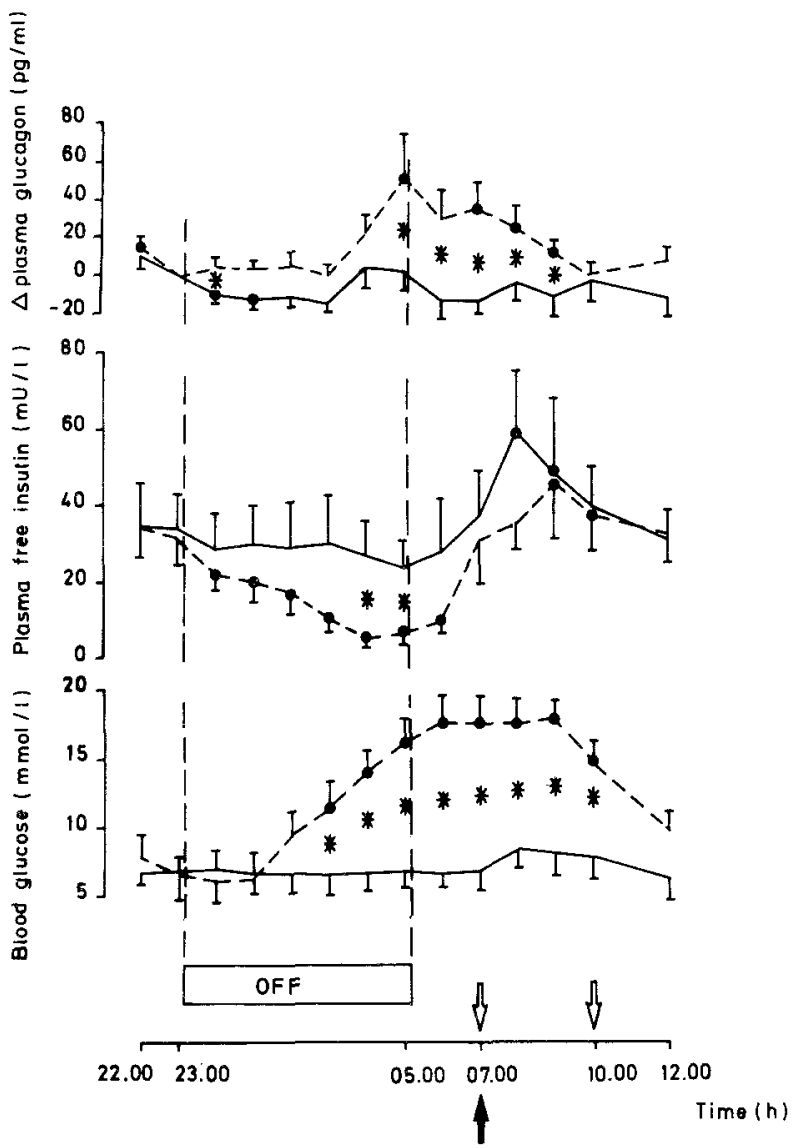

Fig. 1. Changes in blood glucose, plasma free insulin and plasma glucagon levels during normal functioning of the CSII (- - ) and during interruption (-.-). Results are expressed as mean \pm SEM. $*=2 p<0.05$ 'on' versus 'off'; $\bullet=2 p<0.05$ versus 23.00 h value; $n=8$ - =breakfast; $\Delta=$ 'clicks' (boluses of insulin)

each 'click' corresponded to $0.6-1.0 \mathrm{U}$ of insulin; mean $0.9 \pm 0.2 \mathrm{U}$ ) together with additional 'clicks' whose numbers were based on a capillary blood glucose determination using a Dextrostix read on a Glucometer and a ketonuria test using Acetest (Ames Division, Miles Laboratories, Elkhart, Indiana, USA). The additional amounts of insulin were $8 \mathrm{U}$ administrated via the pump if blood glucose was $>$ $22 \mathrm{mmol} / \mathrm{l}$ (whether or not ketonuria was present), $6 \mathrm{U}$ if blood glucose was $>16.5 \mathrm{mmol} / 1$ with ketonuria; $4 \mathrm{U}$ if blood glucose was $>$ $16.5 \mathrm{mmol} / 1$ without ketonuria and $2 \mathrm{U}$ if blood glucose $>11 \mathrm{mmol} / \mathrm{l}$.
At $07.00 \mathrm{~h}$, the patients ate their usual breakfast; at $10.00 \mathrm{~h}$ the same scheme of insulin supplements was applied if blood glucose was > $11 \mathrm{mmol} / 1$ and the protocol ended at $12.00 \mathrm{~h}$. Each subject underwent two tests at random: one as just described (pump off or 'off') and the other which was identical (same timetable; same meals) but without interruption of the CSII (pump on or 'on'). The two tests were separated by at least 2 days. The subjects were asleep in both conditions tested.

\section{Blood Samples and Determinations}

Blood samples were drawn every hour from 22.00 till $12.00 \mathrm{~h}$ the next day (except at $11.00 \mathrm{~h}$ ). Blood glucose was measured using the hexokinase method adapted to the Technicon autoanalyzer, plasma non-esterified fatty acids (NEFA) according to Dole and Meinertz [8], plasma 3-hydroxybutyrate (3-OHB) using an enzymatic assay ( $\beta$-hydroxybutyrate dehydrogenase, Boehringer, Mannheim, FRG), plasma glucagon according to Luyckx [9] using $30 \mathrm{~K}$ antibody (Dr R. H. Unger, Dallas, Texas, USA), plasma growth hormone using the HGHK kit (CIS International, Sorin, Italy), plasma cortisol according to Sulon et al. [11] and plasma C-peptide according to Heding [12]. Plasma free insulin was assayed according to Nakagawa et al. [10]; in each assay, two standard-curves were performed one in the presence, the other in the absence of polyethylene glycol. After adaptation for dilution, both curves fitted perfectly $(r=0.99913)$. The detection limit was $5 \mathrm{mU} / 1$; the intra-assay coefficient of variation was $\pm 4.1 \%$ and the interassay coefficient $\pm 9.6 \%$. For all determinations, samples for the same subjects were assayed in the same radioimmuno- or enzymatic assay.

\section{Statistical Evaluation}

The results are expressed as mean \pm SEM. Statistical evaluation was performed according to the Student's t-test for paired values. All data are compared both between the 'on' and 'off' tests and, within a given test, versus the value recorded at $23.00 \mathrm{~h}$, considered as baseline. For this last comparison, preliminary analysis of variance, using the Anova test, allowed the subsequent use of the Student's t-test.

\section{Results}

\section{Blood Glucose (Fig. 1)}

During the control test ('on'), blood glucose remained constantly within the normal range. In the interruption test ('off'), blood glucose values remained unchanged during the first $2 \mathrm{~h}$ after stopping the pump, and then in- 
Table 2. Plasma cortisol and growth hormone levels in the eight Type 1 diabetic patients without interruption ('on') and with interruption ('off') of CSII

\begin{tabular}{|c|c|c|c|c|c|}
\hline & $23.00 \mathrm{~h}$ & $03.00 \mathrm{~h}$ & $05.00 \mathrm{~h}$ & $08.00 \mathrm{~h}$ & $12.00 \mathrm{~h}$ \\
\hline \multicolumn{6}{|c|}{ Plasma cortisol $(\mu \mathrm{g} / \mathrm{dl})$} \\
\hline 'on' & $3.7 \pm 0.9$ & $6.1 \pm 1.3$ & $10.9 \pm 1.4$ & $14.0 \pm 1.6$ & $11.1 \pm 1.4$ \\
\hline 'off' & $5.1 \pm 1.6$ & $4.9 \pm 1.1$ & $13.6 \pm 2.7$ & $14.1 \pm 1.4$ & $9.2 \pm 1.0$ \\
\hline \multicolumn{6}{|c|}{ Plasma growth hormone $(\mathrm{ng} / \mathrm{ml})$} \\
\hline 'on' & $3.7 \pm 1.5$ & $3.2 \pm 1.2$ & $2.3 \pm 0.8$ & $1.3 \pm 0.2$ & $5.6 \pm 2.2$ \\
\hline 'off' & $3.7 \pm 3.4$ & $2.7 \pm 1.0$ & $2.1 \pm 0.7$ & $3.8 \pm 1.8$ & $1.6 \pm 0.3$ \\
\hline
\end{tabular}

Results are given as mean $\pm \mathrm{SEM}$

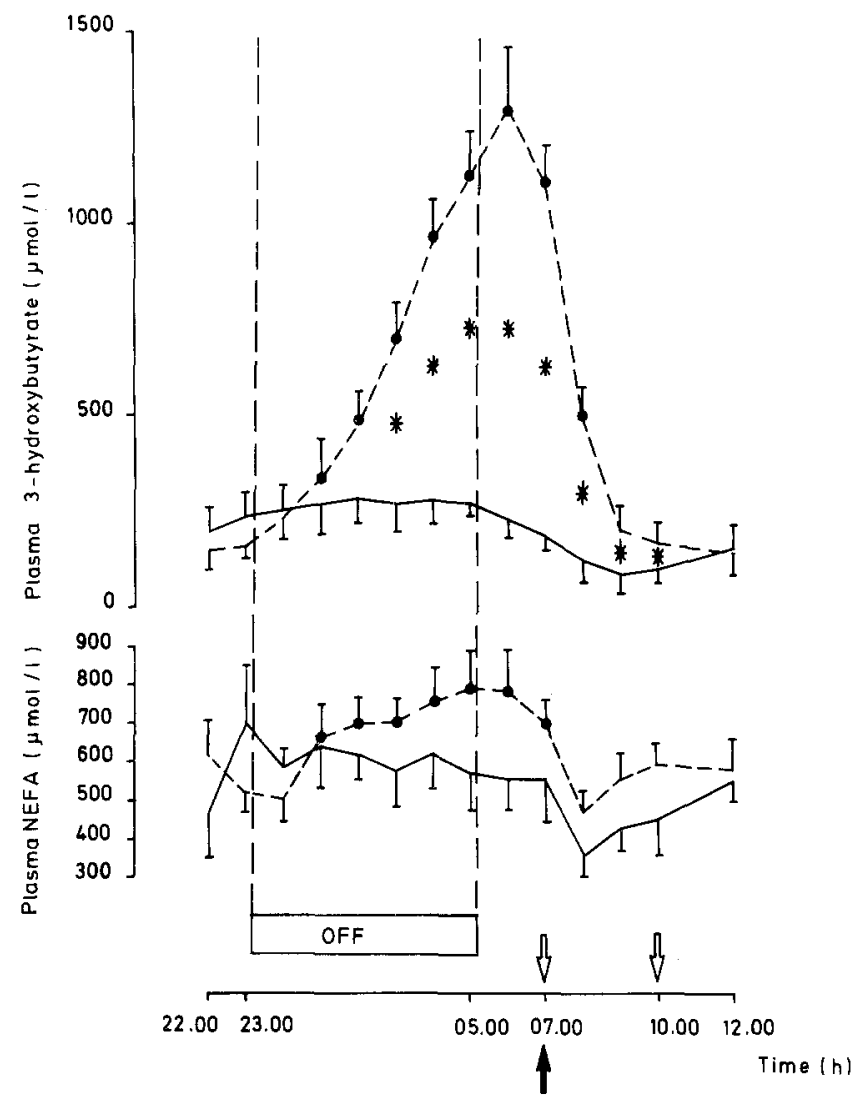

Fig. 2. Changes in plasma non-esterified fatty acids (NEFA) and plasma 3-hydroxybutyrate levels during normal functioning of the CSII (- - ) and during the interruption test (- . - - ). Results are expressed as mean \pm SEM. $*=2 p<0.05$ 'on' versus 'off'; $\bullet=2 p<0.05$ versus $23.00 \mathrm{~h}$ value; $n=8-=$ breakfast; $\diamond=$ 'clicks' (boluses of insulin)

creased regularly from hour 3 after interruption until $1 \mathrm{~h}$ after resetting the pump at its basal rate. The rate of this linear blood glucose rise averaged $0.032 \pm$ $0.003 \mathrm{mmol} \cdot 1^{-1} \cdot \mathrm{min}^{-1}$ between 02.00 and $06.00 \mathrm{~h}$. From 06.00 to $09.00 \mathrm{~h}$, blood glucose values remained stable at approximately $17.5 \mathrm{mmol} / 1$ and then decreased rapidly to reach $10 \mathrm{mmol} / \mathrm{l}$ at $12.00 \mathrm{~h}$. The blood glucose levels in the 'off' tests were significantly different from the $23.00 \mathrm{~h}$ value and from the values recorded in the 'on' test from 03.00 to $10.00 \mathrm{~h}$.

\section{Plasma Free Insulin (Fig. 1)}

During the control test ('on'), plasma free insulin concentration decreased slightly, but not significantly from 35 to $25 \mathrm{mU} / 1$ during the night; it increased markedly and significantly after the breakfast 'clicks' to reach a value of $60 \mathrm{mU} / 1$ at $08.00 \mathrm{~h}$ and then decreased progressively, reaching $30 \mathrm{mU} / 1$ at the end of the study. In the interruption test ('off'), plasma free insulin concentration decreased significantly $1 \mathrm{~h}$ after stopping the pump to reach a nadir of $6 \pm 2 \mathrm{mU} / \mathrm{l}$ at 04.00 and $05.00 \mathrm{~h}$; after resetting the pump at its basal rate between 05.00 and $06.45 \mathrm{~h}$, and after administration of the morning 'clicks', plasma free insulin increased markedly to $45 \pm 15 \mathrm{mU} / 1$ and then decreased at the end of the study to reach a concentration identical to that observed in the control test. Plasma free insulin values were significantly lower in the interruption test ('off') versus the control test ('on') at 04.00 and $05.00 \mathrm{~h}$.

\section{Plasma Glucagon (Fig. 1)}

Results of plasma glucagon determinations were expressed as changes versus the value recorded at $23.00 \mathrm{~h}$ considered as baseline for each subject; these basal values were not significantly different in the two tests $(63 \pm 22$ 'on' versus $45 \pm 22 \mathrm{pg} / \mathrm{ml}$ 'off'). In the control test ('on'), plasma glucagon levels showed no major fluctuations, except a significant decrease between 23.00 and $01.00 \mathrm{~h}$. In the interruption test ('off'), plasma glucagon levels decreased significantly between 22.00 and $23.00 \mathrm{~h}$ but remained stable until $03.00 \mathrm{~h}$; later, glucagon increased by $45 \mathrm{pg} / \mathrm{ml}$ between 03.00 and $05.00 \mathrm{~h}$ and thereafter decreased progressively to reach basal values at the end of the study. Plasma glucagon levels in the interruption test ('off') were significantly different from the basal values $(23.00 \mathrm{~h})$ at $05.00,07.00,08.00$ and $09.00 \mathrm{~h}$ and control test ('on') at $24.00 \mathrm{~h}$ and for all values collected between 05.00 and $09.00 \mathrm{~h}$.

\section{Plasma Non-esterified Fatty Acids (Fig. 2)}

During the control test ('on'), plasma NEFA values remained between 500 and $700 \mu \mathrm{mol} / 1$ until breakfast $(07.00 \mathrm{~h})$ after which NEFA decreased temporarily to 
$350 \pm 62 \mu \mathrm{mol} / 1$ to reach $550 \mu \mathrm{mol} / 1$ again at the end of the study. In the interruption test ('off'), plasma NEFA values were not significantly different from those observed during the normal functioning of the pump ('on'). Nevertheless, levels did increase significantly versus baseline from the hours 2-6 of interruption of the CSII; plasma NEFA levels remained stable for $1 \mathrm{~h}$ and then decreased rapidly until $1 \mathrm{~h}$ after breakfast. At the end of the study, NEFA levels averaged $575 \pm 95$ $\mu \mathrm{mol} / \mathrm{l}$.

\section{Plasma 3-hydroxybutyrate (Fig. 2)}

During the control test ('on') plasma 3-OHB levels remained between 100 and $250 \mu \mathrm{mol} / 1$ throughout the study. In the interruption test ('off'), plasma 3-OHB values increased rapidly and steadily after the interruption of the CSII reaching $1290 \pm 140 \mu \mathrm{mol} / 1$ at $06.00 \mathrm{~h}$. They then decreased quickly until $09.00 \mathrm{~h}$ and, afterwards, remained stable at about $150 \mu \mathrm{mol} / 1$ until the end of the investigation. In the interruption test ('off'), the rise in plasma $3-\mathrm{OHB}$ was statistically significant versus basal value $(23.00 \mathrm{~h})$ from 01.00 to $08.00 \mathrm{~h}$ and the plasma 3-OHB levels were significantly higher than those observed in the control test ('on') from 03.00 to $10.00 \mathrm{~h}$.

\section{Plasma Cortisol and Growth Hormone (Table 2)}

In the control test ('on') as well as in the interruption test ('off'), plasma cortisol levels exhibited their classical circadian variations, without any statistically significant difference between the two experimental conditions.

No significant changes were observed between the growth hormone levels in both conditions.

\section{Discussion}

Numerous recent investigations have emphasized the use of portable pumps for continuous subcutaneous insulin delivery in Type 1 diabetic patients [2-5]. In the present investigation, CSII achieved adequate control of blood glucose, plasma NEFA and 3-hydroxybutyrate but as reported by others $[13,14]$ and confirmed here, at the cost of moderate peripheral hyperinsulinaemia. Most groups with long-term experience of this type of treatment have encountered problems related to inadequate insulin delivery due to battery, motor, syringe or other catheter-needle defects. However, few studies until now have dealt systematically with this crucial question $[7,6]$.

Gerich et al. [15] reported the consequences of abrupt cessation of an intravenous insulin delivery in otherwise perfectly controlled Type 1 diabetic patients: prompt increase in blood glucose, plasma NEFA and 3-hydroxybutyrate, rapid fall in plasma alanine and al- most immediate increase in plasma glucagon. Changes occurring after cessation of a subcutaneous insulin infusion obviously have a different pattern. Champion et al. [7] reported that, in four patients, discontinuation of insulin infusion for $12 \mathrm{~h}$ at night resulted in a moderate increase in blood glucose to reach a mean level of $11.9 \mathrm{mmol} / 1$ (with a range of $8.9-23.3 \mathrm{mmol} / \mathrm{l}$ ) while $3-$ hydroxybutyrate rose to about $2 \mathrm{mmol} / 1$. More recently, Pickup et al. [6] reported their findings in nine patients investigated after deliberately stopping the pump at $09.00 \mathrm{~h}$, the subjects remaining supine and fasting (an attempt to mimic nocturnal conditions) for the next $9 \mathrm{~h}$. A preliminary account of this study on six patients had been published separately by Keen et al. [17]. They reported a virtually linear rise in plasma 3-hydroxybutyrate, while, in contrast, blood glucose did not change during the first hour, rose at a diminishing rate for the next $5 \mathrm{~h}$ and then surprisingly levelled off spontaneously at a plateau of about $5.5 \mathrm{mmol} / 1$ above baseline. It should be pointed out that two of these patients had residual C-peptide secretion. We believe that the interest of our study lies in its particularly strict conditions: patients were all without residual endogenous insulin secretion; subjects were studied at night, a time when this type of incident is more likely to occur and when the hormonal milieu might be quite different from the daytime; a control study with the pump operating has been performed in each patient; and, finally, more metabolites and hormones have been investigated. We have observed that plasma free insulin levels start to decline as soon as $1 \mathrm{~h}$ after interruption of the insulin infusion to reach a nadir during hours 5 and 6 of the interruption. Interestingly, blood glucose remained unchanged during the first $2 \mathrm{~h}$ after discontinuation of the insulin infusion. This observation, in agreement with the findings of Pickup et al. [6], has important implications: a 1-2 h interruption of CSII seems to be well tolerated in terms of blood glucose in well controlled diabetic patients. It remains, however, to investigate the consequences of a $2 \mathrm{~h}$ interruption of CSII followed by a reactivation of the pump at its basal rate. At hour 2 after discontinuation of the insulin infusion, plasma NEFA and 3-hydroxybutyrate levels are clearly increased when compared to the values recorded at $23.00 \mathrm{~h}$. During the last $4 \mathrm{~h}$ of the interruption, plasma NEFA remain elevated while plasma 3-hydroxybutyrate exhibit a steady increase at a rate of $3.3 \pm 0.4 \mu \mathrm{mol} \cdot \mathrm{I}^{-1} \cdot \mathrm{min}^{-1}$. During this period, plasma free insulin levels are falling to minimal values, while, in contrast, plasma glucagon remains unchanged until the last $2 \mathrm{~h}$ of the interruption period when a mean increase of $45 \mathrm{pg} / \mathrm{ml}$ occurs. In agreement with a current theory on the respective roles of insulin and glucagon in the control of hepatic ketogenesis [16], it is suggested that the fall in circulating insulin plays the major role in promoting NEFA mobilization through lipolysis, whereas the fall in the insulin: glucagon ratio (due to both the drop in insulin levels and the later rise in glucagon levels) is involved in 
orienting to ketone body formation the NEFA made available to the liver.

One aim of the present study was to provide patients on CSII with guidelines to restore adequate metabolic control after accidental interruption of the insulin infusion. We have considered that return to control should be achieved: (1) by the patient himself; (2) using the pump as a means of insulin delivery; and (3) on the basis of simple determinations performed by the patient. This scheme, included addition of insulin to the usual pre-breakfast dose (at a moment when, in ordinary conditions, correction should be made) and, if necessary, more supplementary insulin given via the pump $3 \mathrm{~h}$ later. These guidelines have been extremely efficient since, at noon blood glucose had returned from 17.5 to $10 \mathrm{mmol} / 1$ (despite eating a normal breakfast), plasma NEFA and 3-hydroxybutyrate levels were corrected as were circulating insulin and glucagon levels.

In conclusion, the present study has permitted precise characterization of the hormonal and metabolic consequences of a 6-h nocturnal interruption of CSII mimicking spontaneous incidents that indeed occur with this type of treatment [18]. Moreover, precise guidelines have been established which permit the patient to restore adequate metabolic control within a few hours on the basis of simple blood and urine determinations performed by the patient himself.

Acknowledgments. This study was supported by grants of the Fonds National de la Recherche Scientifique and the Fonds de la Recherche Scientifique Médicale of Belgium. We thank the patients who volunteered for this study. We acknowledge the skilfull technical assistance of C. Cartenstadt, Y.Claessens, M. Marchand, C. Borremans, A. Rombaux, M.E.Loumaye and R. Lallemand and the expert secretarial help of E.Vaessen-Petit. M.C. is on leave from the University of Granada, Spain.

\section{References}

1. Pirart J (1977) Diabète et complications dégénératives. Présentation d'une étude prospective portant sur 4400 cas observés entre 1947 et 1973. Diabète Metab 3: 97-107, 173-182 and 245-256

2. Pickup JC, Keen H, Parsons JA, Alberti KGMM (1978) Continuous subcutaneous insulin infusion: an approach to achieving normoglycaemia. Br Med J 1: 204-207

3. Pickup JC, Keen H (1979) Continuous subcutaneous insulin infusion: improved blood-glucose and intermediary-metabolite control in diabetics. Lancet 1: 1255-1258

4. Tamborlane W, Sherwin RS, Genel M, Felig P (1979) Restoration of normal lipid and amino acid metabolism in diabetic patients treated with a portable insulin-infusion pump. Lancet 1: $1258-1261$

5. Keller U, Schade DS (1981) Current status of portable insulin infusion devices. Diabetologia 21: $425-426$

6. Pickup JC, Viberti GC, Bilous RW, Keen H, Alberti KGMM, Home PD, Binder C (1982) Safety of continuous subcutaneous insulin infusion: metabolic deterioration and glycaemic autoregulation after deliberate cessation of infusion. Diabetologia 22 : $175-179$

7. Champion MC, Shepherd GAA, Rodger NW, Dupre J (1980) Continuous subcutaneous infusion of insulin in the management of diabetes mellitus. Diabetes 29: 206-212

8. Dole VP, Meinertz H (1960) Microdetermination of long chain fatty acids in plasma and tissues. $J$ Biol Chem 235: 2595-2599

9. Luyckx AS (1972) Immunoassays for glucagon. In: Lefèbvre PJ, Unger RH (eds) Glucagon, molecular physiology, clinical and therapeutic implications, Pergamon Press, Oxford, pp 285-298

10. Nakagawa S, Nakayama H, Sossaki T, Yoshimo K, Yu Y, Shimozaki K, Aoki S, Mashimo K (1973) Simple method for the determination of serum free insulin levels in insulin-treated patients. Diabetes 22: $590-600$

11. Sulon J, Demey-Ponsart E, Bauduin P, Sodoyez JC (1978) Radioimmunoassay of corticosterone, cortisol and cortisone: their application to human cord and maternal plasma. J Steroid Biochem 9: 671-676

12. Heding LG (1975) Radioimmunological determination of human C-peptide in serum. Diabetologia 11: 541-548

13. Kemmler W, Gerbitz KD, Hauner H, Piwernetz K, Hepp KD, Renner R (1980) The insulin levels necessary for good metabolic control with intravenous insulin therapy. In: Irsigler K, Kunz KN, Owens DR, Regal H (eds) New approaches to insulin therapy, MTP Press, Lancaster, pp 171-179

14. Kraegen EW (1980) The necessity and feasibility of normalizing plasma insulin levels in diabetics using insulin delivery systems. In: Irsigler K, Kunz KN, Owens DR, Regal H (eds) New approaches to insulin therapy, MTP Press, Lancaster, pp 249-256

15. Gerich JE, Lorenzi M, Bier DM, Schneider V, Tsalikian E, Karam JH, Forsham PH (1975) Prevention of human diabetic ketoacidosis by somatostatin. Evidence for an essential role of glucagon. $\mathrm{N}$ Engl J Med 292: 985-989

16. McGarry JD, Foster DW (1980) Regulation of hepatic fatty acid oxidation and ketone body production. Ann Rev Biochem 49: $395-420$

17. Keen H, Pickup JC, Viberti GC, Bilous R, Williams G (1981) Aspects of continuous subcutaneous insulin infusion in diabetes. Diabetes Care 4: 54-57

18. Fishman V, Fishman M (1982) Practical problems with insulin pumps. New Engl J Med 306: 1369

Received: 21 May 1982

and in revised form: 2 November 1982

Dr. P.J.Lefèbvre

Institut de Médecine

Hôpital de Bavière

Boulevard de la Constitution, 66

B-4020 Liège

Belgium 